\title{
Sistem Pengambil Keputusan untuk Menentukan Kelayakan Penerima Kredit Mobil di PT. Adira Finance Cabang Kota Pasuruan
}

\author{
Prakasa Putra Irawan ${ }^{1}$, M. Misdram² ${ }^{2}$ Ratih Fitri Aini ${ }^{3}$
}

\begin{abstract}
Intisari- PT. Adira Finance Cabang Kota Pasuruan merupakan salah satu perusahaan yang bergerak di bidang pembiayaan dan asuransi kendaraan. Selama ini kebijakan kelayakan pemberian kredit mobil kepada pelanggan masih menggunakan cara konvensional, sehingga tidak efisien karena membutuhkan waktu yang lama untuk memberikan kelayakan pemberian kredit kepada pelanggan. Oleh karena itu, dibutuhkan aplikasi yang berguna sebagai alat bantu pengambilan keputusan bagi pimpinan untuk memberikan kredit kepada pelanggan dan mempermudah pelanggan dalam penyampaian informasi tentang pengajuan kreditnya. Metode penelitian yang digunakan adalah penelitian lapangan, wawancara dan penelitian kepustakaan. Penentuan kelayakan penerima kredit menggunakan metode Five C. Hasil yang didapatkan adalah aplikasi Sistem Penunjang Keputusan Kredit ini mampu mempermudah pengambil keputusan dalam menentukan kelayakan seorang pelanggan dalam menerima kredit serta dapat menangani proses peng-update data pelanggan, data mobil, dan proses pembuatan laporan sehingga memiliki dokumentasi perangkat lunak yang cukup baik.
\end{abstract}

Abstrack- PT. Adira Finance branch at Pasuruan city is one of enterprise that budged in funding sector and vehicle insurance. Advisability policy give credit a car for customer still use conventional method and need a lot of time to give advisability policy give credit to customer. The purpose of this study is to built a software as device to help make decision for the leader in giving credit to customer and to make easier the customer in delivery information about submission their credit. The methodology of this research is field research, interview and library research. Determination of the feasibility of using five credit recipient C. Decision Support System credit aplication can make easier in take a decision to determine advisability a customer in accept credit. It can take in hand a process for renewal customer data, the data of car, and the reporting process so. It have documentation about a good software.

\section{Kata Kunci-Decision Support System, Credit, Five C}

${ }^{1}$ Mahasiswa, Jurusan Teknik Informatika Fakultas Teknologi Informasi Universitas Merdeka Pasuruan, Jalan Ir. H. Juanda No 68 Pasuruan INDONESIA ( e-mail: wahyu.sulistiyarini@gmail.com)

2,3 Dosen, Jurusan Teknik Informatika Fakultas Teknologi Informasi Universitas Merdeka Pasuruan, Jalan Ir. H. Juanda No 68 Pasuruan INDONESIA (e-mail: misdram@yahoo.co.id)

\section{PENDAhuluan}

A. Latar Belakang

PT. Adira Finance Cabang Kota Pasuruan merupakan salah satu perusahaan yang bergerak di bidang pembiayaan dan asuransi kendaraan. Kebijakan kelayakan pemberian kredit mobil kepada pelanggan PT. Adira Finance cabang Kota Pasuruan masih menggunakan cara konvensional, yaitu sebatas pencatatan menggunakan Microsoft Word atau Microsoft Excel sehingga tidak efisien karena membutuhkan waktu yang lama untuk memberikan kelayakan pemberian kredit kepada pelanggan. Selain itu kendala terbesar adalah kesulitan dalam penyimpanan atau pencarian arsip yang telah tersimpan jika akan dicocokkan dengan informasi atau pedoman yang baru diperoleh, karena masih tidak adanya sistem database yang menangani. Serta tidak lupa juga terkait masalah informasi kepada pelanggan tentang penerimaan kredit yang diajukan. Hal ini terjadi karena tidak adanya sistem di dalam PT. Adira Finance Cabang Kota Pasuruan yang khusus menangani tentang adanya pengambilan keputusan untuk menentukan kelayakan penerimaan kredit mobil. Untuk penentuan kelayakan penerima kredit mobil di PT Adira Finance Cabang kota pasuruan menggunakan metode Five C yaitu Capital (kemampuan yang dimiliki nasabah), Capacity (Kapasitas nasabah dalam melunasi kredit), Collateral (Jaminan yang dimiliki nasabah untuk menanggung resiko kredit), Condition (Kondisi keuangan nasabah) dan Charakter (karakter nasabah).

Pengembangan sistem informasi berbasis desktop merupakan bagian dari pengembangan sistem (system development), dalam hal ini pengembangan sistem dapat berarti membangun suatu sistem yang baru untuk menggantikan sistem yang lama secara keseluruhan atau memperbaiki sistem yang sudah ada. Dengan digunakannya sistem ini diharapkan dapat membantu pimpinan perusahaan dalam pengambilan suatu keputusan.

\section{TINJAUAN PUSTAKA}

\section{A. Sistem Penunjang Keputusan}

Sistem penunjang keputusan merupakan sistem berbasis komputer yang diharapkan dapat membantu menyelesaikan masalah-masalah yang komplek yang tidak terstruktur maupun yang semi terstruktur. Sistem Penunjang Keputusan merupakan perpaduan antara keahlian manusia dan juga komputer. Dengan kemampuan yang dimiliki, sistem penunjang keputusan diharapkan dapat membantu dalam pengambilan keputusan baik untuk masalah semi terstruktur maupun tidak terstruktur [1]. 


\section{B. Visual Basic 6.0}

Microsoft Visual Basic 6.0 (biasa disingkat VB) adalah salah satu produk bahasa pemrograman yang dikeluarkan Microsoft, salah satu perusahaan software terkemuka didunia. Visual Basic 6.0 merupakan bahasa pemrograman yang mudah digunakan untuk pengembangan aplikasi, baik aplikasi kecill maupun aplikasi besar. Dengan banyaknya komponen kontrol yang disediakan oleh Visual Basic 6.0, membuat para programmer dan pengembang aplikasi lebih mudah dalam membuat aplikasi [2].

\section{SQL Server}

Microsoft SQL Server adalah sebuah sistem manajemen basis data relasional (RDBMS) produk Microsoft. Bahasa kueri utamanya adalah Transact-SQL yang merupakan implementasi dari SQL standar ANSI/ISO yang digunakan di dunia bisnis yang memiliki basis data berskala kecil sampai menengah, tetapi kemudian berkembang dengan digunakannya SQL Server pada basis data besar [3].

\section{PT. Adira Finance}

PT Adira Dinamika Multi Finance Tbk (Adira Finance) didirikan pada tahun 1990 dan mulai beroperasi pada tahun 1991. Sejak awal Perusahaan telah berkomitmen untuk menjadi perusahaan yang terbaik dan terkemuka di sektor pembiayaan yang melayani pembiayaan beragam merek, baik untuk sepeda motor maupun mobil, baru maupun bekas [4].

\section{ANALISA DAN PERANCANGAN SISTEM}

\section{A. Analisa Pemecahan Masalah}

Penentuan kelayakan penerima kredit mobil di PT Adira Finance Cabang kota pasuruan menggunakan metode Five C, dimana kemudian metode Five $\mathrm{C}$ ini diterjemahan kedalam 10 poin varibel yaitu :

1) Capital (kemampuan yang dimiliki nasabah) : gaji nasabah.

2) Capacity (Kapasitas nasabah dalam melunasi kredit) : tempat tinggal nasabah, pekerjaan, jabatan.

3) Collateral (Jaminan yang dimiliki nasabah untuk menanggung resiko kredit) : jaminan rumah, jaminan tanah.

4) Condition (Kondisi keuangan nasabah) : rekening tabungan

5) Charakter (karakter nasabah) : kartu keluarga, kartu tanda penduduk (KTP), persetujuan Suami/ Istri (bila yang sudah menikah)

Dari 10 poin diatas kemudian terdapat nilai yang akan menjadi acuan dalam pengambilan keputusan seperti di bawah ini

1) Gaji Nasabah
- Gaji $\geq 10$ Juta
: 10 poin
- 4 Juta $\leq$ Gaji < 10 Juta
: 9 poin
- 3 Juta $\leq$ Gaji $<5$ Juta
$: 8$ poin
- 2 Juta $\leq$ Gaji $<4$ Juta
$: 7$ poin

2) Tempat tinggal

- Kota Pasuruan

: 10 poin

- Kabupaten Pasuruan

: 9 poin

- Luar Kota/Kab. Pasuruan

: 8 poin

3) Pekerjaan

- PNS

- Wiraswasta

: 10 poin

- Pensiunan PNS

: 9 poin

- ABRI/Polisi

$: 8$ poin

- Pensinan ABRI/Polisi

$: 7$ poin

: 6 poin

4) Jabatan.

- PNS

Golongan IV

$: 10$ poin

Golongan III

: 9 poin

Golongan II

: 8 poin

Golongan I

: 7 poin

- Pensiunan PNS

Golongan IV : 8 poin

Golongan III $: 6$ poin

Golongan II $: 7$ poin

Golongan I : 5 poin

- Wiraswasta

Masa Kerja $\geq 15$ Tahun :9 poin

10 Tahun $\leq$ Masa Kerja $<15$ Tahun $: 8$ poin

5 Tahun $\leq$ Masa Kerja $<10$ Tahun $: 7$ poin

1 Tahun $\leq$ Masa Kerja $<5$ Tahun $: 6$ poin

- ABRI/Polisi

Perwira

$: 8$ poin

Bintara

$: 6$ poin

Prajurit

: 7 poin

- Pensinan ABRI/Polisi

$\begin{array}{ll}\text { Perwira } & : 6 \text { poin } \\ \text { Bintara } & : 5 \text { poin } \\ \text { Prajurit } & : 4 \text { poin }\end{array}$

5) Jaminan Rumah

- Kec. Bugul Kidul tipe 45 kebawah : 1 poin

- Kec. Bugul Kidul tipe 60 ketas : 2 poin

- Kec. Panggunrejo tipe 45 kebawah : 3 poin

- Kec. Panggunrejo tipe 60 ketas : 4 poin

- Kec. Gadingrejo tipe 45 kebawah : 5 poin

- Kec. Gadingrejo tipe 60 ketas : 6 poin

- Kec. Purworejo tipe 45 kebawah : 7 poin

- Kec. Purworejo tipe 60 ketas : 8 poin

6) Jaminan Tanah.

- Diluar area kerja $\quad: 1$ poin

- Kec. Bugul Kidul 100-200 m² : 2 poin 
- Kec. Bugul Kidul $200 \mathrm{~m}^{2}$

$: 3$ poin

- Kec. Panggunrejo 100-200 $\mathrm{m}^{2}$

$: 4$ poin

- Kec. Panggunrejo $200 \mathrm{~m}^{2}$

$: 5$ poin

- Kec. Gadingrejo 100-200 $\mathrm{m}^{2}$

$: 6$ poin

- Kec. Gadingrejo $200 \mathrm{~m}^{2}$

$: 7$ poin

- Kec. Purworejo 100-200 m²

$: 8$ poin

- Kec. Purworejo $200 \mathrm{~m}^{2}$

$: 9$ poin

7) Rekening Tabungan

- 0,750 - 1 juta dan mutasi tidak aktif : 1 poin

- 0,750 - 1 juta dan mutasi aktif : 2 poin

- 1 - 2 juta dan mutasi tidak aktif : 3 poin

- 1 - 2 juta dan mutasi aktif : 4 poin

- 2 - 5 juta dan mutasi tidak aktif : 5 poin

- 2 - 5 juta dan mutasi aktif :6 poin

- 5 - 10 juta dan mutasi tidak aktif : 7 poin

- 5 - 10 juta dan mutasi aktif :8 poin

- $\geq 1$ juta dan mutasi tidak aktif $: 9$ poin

- $\geq 1$ juta dan mutasi aktif : 10 poin

8) Kartu Keluarga

- $0 \leq$ jumlah $<3$

$: 10$ poin

- $3 \leq$ jumlah $<5$

: 9 poin

- $5 \leq$ jumlah $<7$

$: 8$ poin

- jumlah $\geq 7$

$: 7$ poin

9) SK Jabatan

: 10 Poin

10) Persetujuan Suami/ Istri

: 10 Poin

Kemudian hasil pemjumlahan poin nasabah akan dibandingkan dengan poin mobil sebagai rekocendasi hasil keputusan. Poin mobil ditentukan berdasarkan harga. Adapun poin mobil sebagai berikut:
1) Harga mobil $\geq 110$ juta
: 90 Poin
2) 100 juta $\leq$ harga mobil < 110 juta
: 80 Poin
3) 90 juta $\leq$ harga mobil < 100 juta
: 70 Poin

\section{B. Rancangan Program}

Pada pembuatan aplikasi ini, diperlukan beberapa tahapan perancangan sistem. Perancangan dimulai dengan mendesain flowchart input data yang akan di gunakan sebagai pertimbangan dalam menentukan keputusan. Salah satu data yang dibutuhkan dalam sistem adalah data nasabah. Dimana langkah-langkah input nasabah dimulai dari data nasabah, kemudian data nasabah tersebut di inputkan kesistem, dan inputan data nasabah tersebut disimpan ke tabel nasabah. yang terdapat pada database.

Selain data nasabah, data yang dibutuhkan juga data varibel seperti yang telah dijelaskan di subbab 2 analisa pemecahan masalah, dan data mobil beserta harganya. Setelah semua data lengkap, dapat dilakukan perhitungan. sehingga akhirnya dapat di ketahui rekomendasi dari sistem tentang pelayakan penerima kredit. Dalam Gambar 1 disebutkan bahwa data-data yang dibutuh untuk pendukung keputusan sebagai data survey

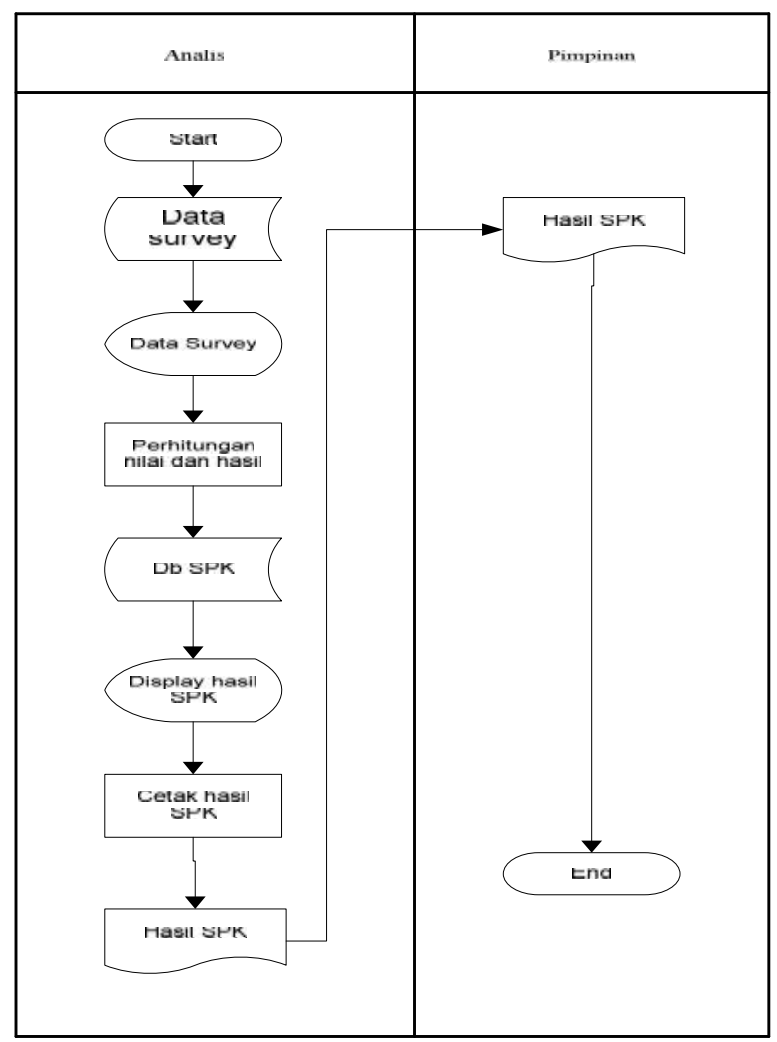

Gambar 1. Flowchart Sistem Pendukung Keputusan

\section{HASIL}

Setelah proses analisa dan perancangan sistem kemudian dilakukan proses pembuatan sistem. Hasilnya berupaya aplikasi desktop. Tampilan yang muncul pertama ketika aplikasi dijalankan adalah tampilan login seperti pada Gambar 2.

Setelah login berhasil, aplikasi akan menampikan halaman utama. Pada halaman utama tersedia pilihan menu untuk menasukan data survey, mulai dari data nasabah,data mobil, pengajuan kredit sampai menu untuk melihat laporan persetujuan pengajuan kredit.

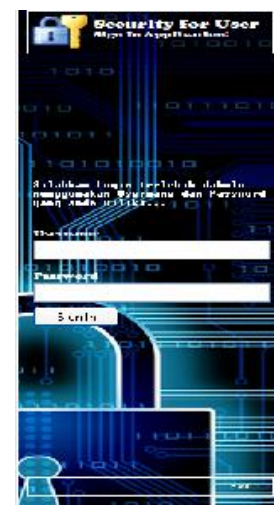

Gambar 2. Tampilan Login

Gambar 3 merupakan salah satu from yang terdapat pada aplikasi sistem pendukung keputusan kelayakan penerima 
kredit mobil ini. Gambar tersebut menampilkan form transaksi pengajuan kredit. Data-data yang harus diisi pada proses transaksi pengajuan adalah no pengajuan yang dibuat secara automatis oleh sistem, tanggal pengajuan yang diambil dari tanggal ketika data dimasukkan, id nasabah. Dari id nasabah inilah akan diketahui nama lengkap, jenis kelamin, dan data lainnya tentang data nasabah karena telah tersimpan dalam database. Setelah data pengajuan transaksi lengkap barulah rekomendasi pemberian kredit pada nasabah dapat diketahui.

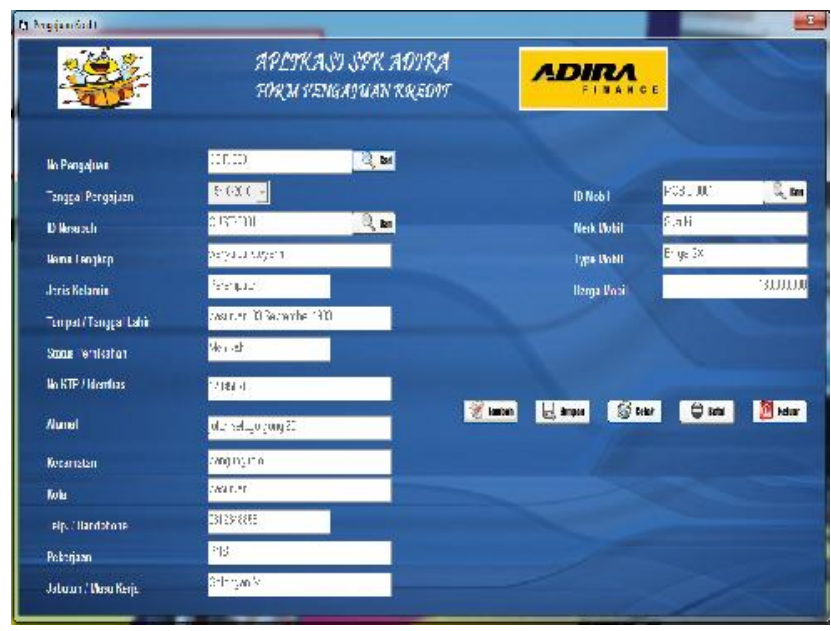

Gambar 3. Form Transaksi Pengajuan Kredit

Laporan hasil persetujuan pemberian kredit pada periode tertentu juga dapat dilihat kembali melalui menu laporan persetujuan kredit. Untuk menampilkan kembali laporan persetujuan kredit harus dilakukan pengisian tanggal awal dan tanggal terakhir dari periode yang akan ditampilan hasil rekomendasinya. Gambar 4 menunjukkan tampilan menu laporan hasil persetujuan pemberian kredit.

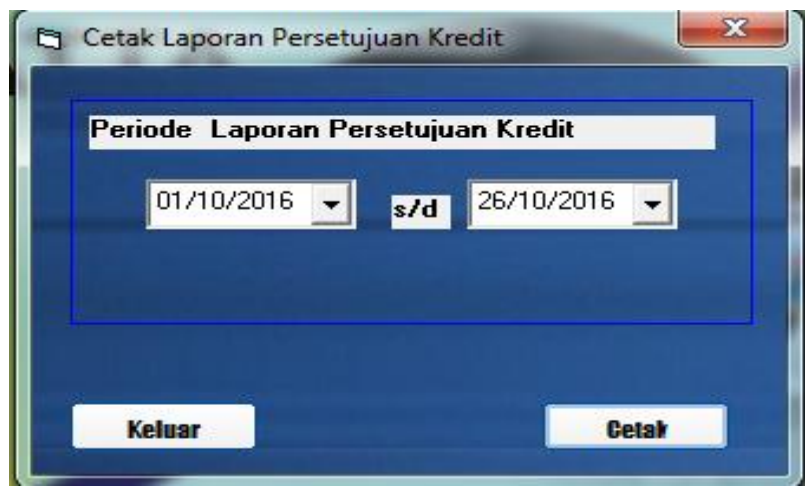

Gambar 4. Form Laporan Persetujuan Kredit

Aplikasi pendukung keputusan kelayakan pemberi kredit mobil ini telah dapat digunakan untuk mempermudah pengambilan keputusan pemberian kredit mobil.

\section{PENUTUP}

\section{A. Kesimpulan}

Berdasarkan hasil penelitian yang telah dilakukan dapat mengambil kesimpulan bahwa aplikasi SPK Kredit mampu mempermudah pengambil keputusan dalam menentukan kelayakan seorang pelanggan dalam menerima kredit dan menangani proses peng-update data pelanggan, data mobil, dan proses pembuatan laporan sehingga memiliki dokumentasi perangkat lunak yang cukup baik.

\section{B. Saran}

Masukan - masukan yang dapat diberikan untuk memperbaiki kinerja dan kelengkapan sistem dapat berupa:

1. Sistem ini hanya digunakan untuk kebutuhan single user, karenanya untuk pengembangan selanjutnya diharapkan akan menggunakan sistem multi user untuk pengintegrasian data pada PT. Adira Finance seluruh Indonesia.

2. Pembangunan Sistem Informasi yang lebih luas sehingga dapat mencakup seluruh prosedur perkreditan yang ada ( kapasitas melunasi kredit, penagihan kredit dll.)

\section{Ucapan Terima Kasih}

Terselesaikannya penulisan dalam jurnal ini adalah berkat kerja keras dan bimbingin dari para dosen di Jurusan Teknik Informatika Universitas Merdeka Pasuruan, Penulis menyampaikan ucapan terima kasih dan Apresiasi kepada para dosen yang telah membina dan meluangkan waktunya hingga selesai penelitian ini. Kepada Jointecs kami ucapkan terima kasih sehingga terpublikasi artikel ilmiah ini setelah melalui proses revisi.

\section{Referensi}

[1] Turban, E, Aronson, EJ, and Liang. (2001). Ting Peng, Decision Support System and Intelligent System. 6th Edition. Upper Saddle River: Prentice-Hall

[2] Kusrini, Andri Koniyo. 2007. Tuntunan Praktis Membangun Sistem Informasi Akuntansi dengan Visual Basic dan Microsoft SQL Server. Yogyakarta: ANDI

[3] Fauzi, M. Miftakul Amin. 2012. Pemrograman Database Visual Basic 6 dan SQL Server 2000. Yogyakarta: ANDI.

[4] http://adira.co.id/dasar-dasar-pendirian-perusahaan 